GOSPODARKA SUROWCAMI MINERALNYMI - MINERAL RESOURCES MANAGEMENT

\title{
The changes in the structure of mineral raw materials needs in Poland between 2011-2015
}

\section{Introduction}

Mineral raw materials underpin the functioning of the modern economy. Guaranteeing their adequate supply is a condition of harmonious development of the industry and safeguarding of the society's needs. The majority of both basic common goods as well as high-tech products which are needed in everyday life would not have been created without utilization of e.g.: steel, copper, nickel, chromium and other metals, feldspar, kaolin or ceramic clays among industrial minerals, fuels such as natural gas, petroleum, coke, hard coal or lignite, and wide range of chemical raw materials including e.g.: rock salt, sulphur, magnesites, phosphates or potassium salts.

In Poland, almost all the domestic mining production of many mineral raw materials is consumed by the indigenous industry. Simultaneously, due to the lack of deposits of some minerals along with insufficient manufacturing capacities of the existing plants, and sometimes as a result of price competition on the domestic and foreign markets, substantial amounts of mineral raw materials have to be imported (Bilans... 2015; Galos and Szamałek 2011; Szamałek 2011).

Technological progress, involving increased use of secondary and waste materials coupled with miniaturization, results in reduced demand for some minerals. This is also encouraged by restructuring and modernization of the Polish industry that is accompanied by the

* Ph.D. Eng., ** M.Sc. Eng., Mineral and Energy Economy Research Institute, Polish Academy of Sciences, Krakow, Poland; e-mail: lewicka@min-pan.krakow.pl; burkowicz@min-pan.krakow.pl 
introduction of innovative manufacturing processes characterized by reduced consumption of energy and materials (Galos et al. 2010; Nieć et al. 2014). Simultaneously - due to the emergence and further development of new technologies, especially in the electronics and electrotechnics, the demand for many raw materials is on the rise. This is exemplified especially by: rare earths, antimony, tin, silicon, some ferroalloys, graphite etc. This article aims to estimate the current mineral raw materials needs of the domestic economy and to examine possible ways of facing these needs from indigenous and foreign sources taking the statistics of production and trade in the years 2011-2015 into account.

\section{Estimated value and volume of mineral raw materials consumption in Poland}

The consumption volume and value of the majority raw materials in Poland was evaluated on the basis of the production and trade data coming from the Central Statistical Office (GUS), and sometimes - directly from the producers. Most of these figures refer to the socalled apparent consumption, which is the difference between the value/volume of supply (production+imports) and exportation, excluding stock changes. Applying the above formula to evaluating the demand can result in negative values/volumes of apparent consumption (if foreign sales exceed domestic supplies, as it can be observed in the case of soda ash or asphalt, Table 1). Only for some mineral raw materials, i.e. sulphur, aluminum, coke, lignite, hard coal, real demand level is known (Galos and Lewicka 2016; Minerals Yearbook... 2014). The results obtained from the calculation were the basis for the assessment of the share of a particular group of minerals in the overall domestic demand in terms of value or volume. The following groups of mineral raw materials were examined: fuels, metallic, ceramic, chemical, construction, and others - of different or mixed manner of utilization in comparison to the previously-mentioned ones. The shares of selected mineral raw materials were also estimated within the groups concerned (with the exclusion of natural gas, nitrogen and argon, due to units of measurements other than metric tons).

Among the analyzed groups the highest values of demand were showed by fuels (excluding natural gas, due to the lack of data). In the years 2011-2014 the share of this group in the total value of demand was $70-74 \% / y$, while in $2015-66 \%$ (Fig. 1). That was determined by crude oil representing $61-70 \% / y$ within the group of fuels as well as - albeit to a lesser extent - hard coal $(25-33 \% / y)$ (Table 1). The values of consumption of these minerals were characterized by significant variations, while the whole group since 2012 showed a clear decline of its share in the total consumption resulting from price reduction both in the domestic and foreign markets. A significantly lower, but stable percentage was accounted for metallic raw materials until $2014(11-12 \% / y)$ with refined copper being the most important (46-54\%/y of demand within the group). In 2015 the relative increase of metals' share in the total consumption value took place (in favor of fuels), which was followed by the rise in costs of consumption of copper concentrates and aluminum, as well as refined lead and metallic 
zinc. The opposite trends were observed for refined copper or iron ores and concentrates, the costs of consumption of which were clearly reduced due to a slump on the international market of metals. Similar shares in the total value of consumption were recorded for ceramic raw materials $(6-8 \% / y$, including cement $53-60 \% / y$ of demand within group, and limestone $16-18 \% / y)$ and chemical raw materials $(5-7 \% / y$, including nitrogen-based fertilizers $69-78 \% / y$ of demand within group, and potassium salts $15-18 \% / y$ ) among non-metallic raw materials, while construction ones accounted for 3-5\%/y (Fig. 1, Table 1).

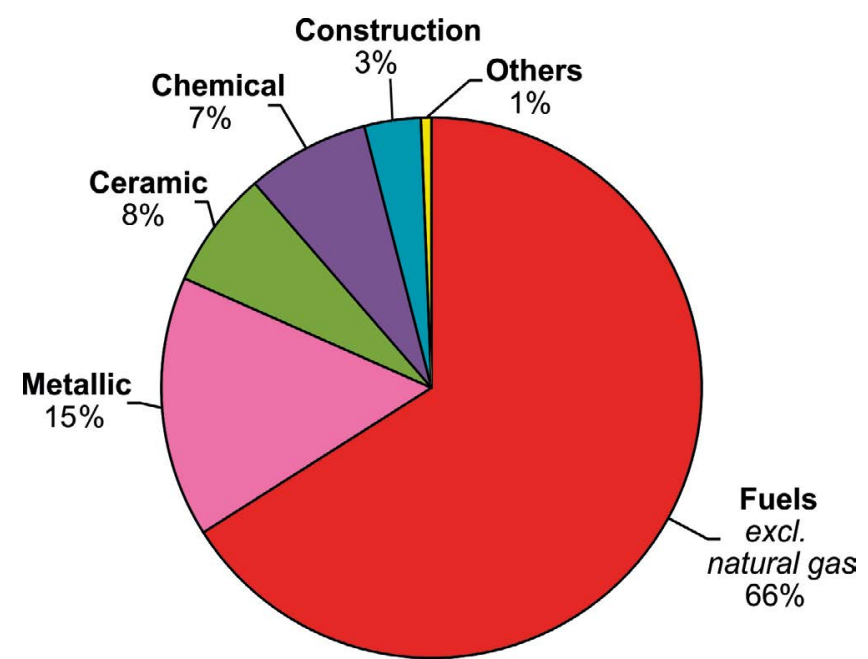

Fig 1. The estimated structure of demand value of mineral raw materials consumed in Poland by groups, 2015 (\%) (GUS, own calculations)

Rys. 1. Szacunkowa struktura wartości zapotrzebowania na surowce mineralne w Polsce w $2015 \mathrm{r}$. według grup (\%) (GUS, obliczenia własne)

The total value of the demand for mineral raw materials in Poland was reduced from 124-126 billion zlotys per year in 2011-2012 to just 92 billion zlotys in 2015, i.e. by around $27 \%$. This was mostly influenced by fuels, for which the consumption value decreased by around $35 \%$, partly as a result of the implementation of energy-efficiency innovative solutions in the domestic industry.

Somewhat different proportions can be observed in the case of the quantification of the domestic demand for mineral raw materials (Fig. 2, Table 2). The largest, though comparable contributions have two groups, both utilized in huge amounts in the country's economy, i.e.: fuels (excluding natural gas) $-33-39 \% / y$ ( $44-48 \% / y$ of which correspond to hard coal, $36-39 \% / y$ to lignite, and only $14-16 \% / y$ to crude oil), as well as construction raw materials $-33-41 \% / y$ (of which $52-55 \% / y$ was the consumption of sand and gravel natural aggregates, $41-44 \% / y$ - crushed aggregates, and only $3-4 \% / y$ - construction and road stones). 
Table 1. The estimated structure ${ }^{1}$ of demand value of mineral raw materials consumed in Poland in groups, 2011-2015 (\%)

Tabela 1. Szacunkowa struktura wartości zapotrzebowania na surowce mineralne w Polsce w latach 2011-2015, w podziale na grupy $(\%)$

\begin{tabular}{|c|c|c|c|c|c|}
\hline Group of mineral raw materials/a mineral raw material & 2011 & 2012 & 2013 & 2014 & 2015 \\
\hline Fuels excl. natural gas & 71 & 74 & 72 & 70 & 66 \\
\hline Crude oil & 61 & 70 & 68 & 69 & 61 \\
\hline Hard coal & 33 & 25 & 27 & 25 & 32 \\
\hline Lignite & 5 & 5 & 5 & 5 & 7 \\
\hline Coke & 1 & 1 & 0 & 0 & 1 \\
\hline Metallic & 12 & 11 & 12 & 12 & 15 \\
\hline Refined copper & 47 & 54 & 47 & 50 & 46 \\
\hline Aluminium metal & 15 & 15 & 13 & 14 & 16 \\
\hline Copper concentrates & 2 & 2 & 6 & 8 & 11 \\
\hline Iron ores and concentrates & 14 & 15 & 15 & 13 & 9 \\
\hline Refined lead & 6 & 6 & 7 & 6 & 7 \\
\hline Zinc metal & 4 & 6 & 5 & 2 & 4 \\
\hline Copper-smelter, non-refined & 5 & 4 & 3 & 2 & 3 \\
\hline Zinc concentrates & 1 & 3 & 2 & 2 & 2 \\
\hline Ferroalloys & 0 & 0 & 0 & 2 & 2 \\
\hline Pig iron & 2 & 1 & 1 & 1 & 1 \\
\hline Nickel metal & 1 & 1 & 0 & 0 & 1 \\
\hline Titanium ores and concentrates & 1 & 1 & 1 & 1 & 1 \\
\hline Magnesium & 0 & 0 & 1 & 1 & 1 \\
\hline Others & 0 & -11 & 0 & -1 & -3 \\
\hline Ceramic & 7 & 6 & 6 & 7 & 8 \\
\hline Cement & 60 & 57 & 54 & 55 & 53 \\
\hline Limestone & 16 & 18 & 16 & 17 & 16 \\
\hline Lime & 6 & 5 & 5 & 5 & 6 \\
\hline Magnesite: calcined, dead-burned, fused & 3 & 2 & 2 & 3 & 3 \\
\hline Dolomite, raw & 1 & 2 & 2 & 2 & 2 \\
\hline
\end{tabular}

1 For the group of mineral raw materials the percentage refers to the total value of consumption; for a particular mineral the percentage refers to the consumption value of a group. 
Table 1. cont.

Tabela 1. cd.

\begin{tabular}{|c|c|c|c|c|c|}
\hline Group of mineral raw materials/a mineral raw material & 2011 & 2012 & 2013 & 2014 & 2015 \\
\hline Clays, refractory & 2 & 2 & 2 & 2 & 2 \\
\hline Synthetic corundum & 1 & 2 & 2 & 2 & 2 \\
\hline Clays, stoneware & 2 & 2 & 1 & 2 & 2 \\
\hline Alumina & 1 & 2 & 2 & 2 & 2 \\
\hline Chalk & 1 & 1 & 2 & 2 & 2 \\
\hline Others & 8 & 8 & 11 & 10 & 9 \\
\hline Chemical & 5 & 5 & 5 & 6 & 7 \\
\hline Nitrogen-based fertilizers & 69 & 73 & 73 & 76 & 78 \\
\hline Potash & 17 & 18 & 16 & 16 & 15 \\
\hline Sulphur, elemental & 4 & 4 & 3 & 3 & 4 \\
\hline Salt & 6 & 4 & 7 & 5 & 3 \\
\hline Phosphorus & 2 & 2 & 3 & 3 & 3 \\
\hline Nitric acid & 3 & 2 & 1 & 1 & 2 \\
\hline Phosphate fertilizers & 1 & 2 & 1 & 2 & 1 \\
\hline Calcined soda & -4 & 0 & 0 & 1 & 1 \\
\hline Others & 1 & -6 & -5 & -6 & -7 \\
\hline Construction & 5 & 3 & 5 & 5 & 3 \\
\hline Natural aggregates - crushed & 46 & 46 & 25 & 26 & 50 \\
\hline Natural aggregates - sand and gravel & 38 & 41 & 24 & 24 & 44 \\
\hline Construction and road stones & 16 & 19 & 10 & 13 & 20 \\
\hline Asphalts & 0 & -5 & 41 & 37 & -14 \\
\hline Others & 1 & 1 & 1 & 1 & 1 \\
\hline Total value (billion zlotys) & 124 & 126 & 122 & 112 & 92 \\
\hline
\end{tabular}

Source: (GUS, own calculations).

In the case of fuels, it is worth noting the systematic relative decline in the consumption costs of hard coal with reference to crude oil. The two times lower proportion fell at ceramic minerals $-17-18 \% / y(45-47 \% / y$ of which was represented by limestone, $20-$ $-22 \% / y$ - by cement, and $14-15 \% / y$ - by cement clinker), while even smaller percentage $4-5 \% / y-$ at chemical raw materials. The group of metals, with the share of $5-6 \% / y$ 


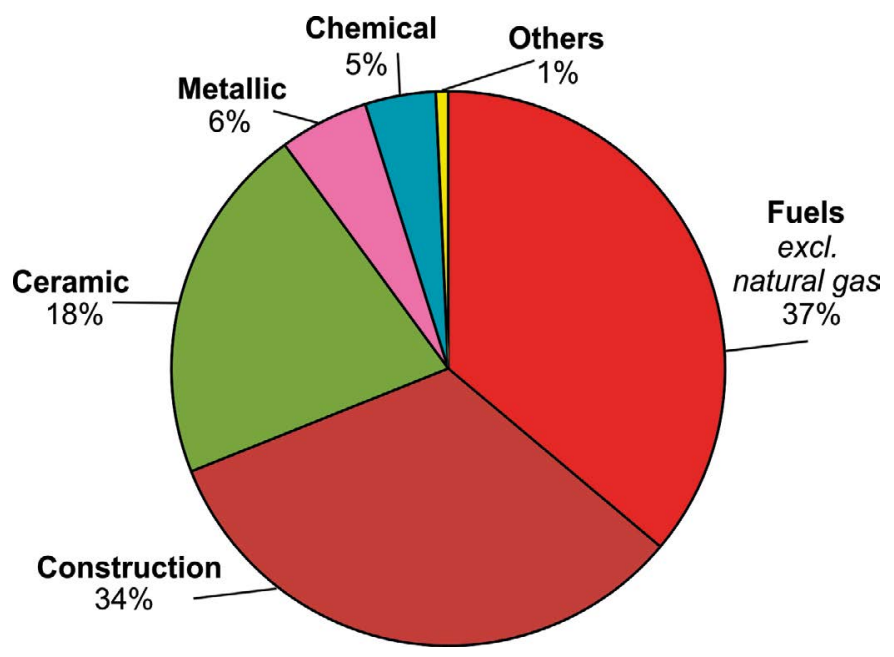

Fig. 2. The estimated structure of demand volume of mineral raw materials consumed in Poland by groups, 2015 (\%) (GUS, own calculations)

Rys. 2. Szacunkowa struktura wielkości zapotrzebowania na surowce mineralne w Polsce w 2015 r. według grup (\%) (GUS, obliczenia własne)

Table 2. The estimated structure of demand ${ }^{1}$ by volume of mineral raw materials consumed in Poland in groups, 2011-2015 (\%) (GUS, own calculations)

Tabela 2. Szacunkowa struktura wielkości zapotrzebowania na surowce mineralne w latach 2011-2015 w podziale na grupy (\%) (GUS, obliczenia własne)

\begin{tabular}{|l|c|c|c|c|c|}
\hline $\begin{array}{c}\text { Group of mineral raw materials/ } \\
\text { a mineral raw material }\end{array}$ & 2011 & 2012 & 2013 & 2014 & 2015 \\
\hline Fuels excl. natural gas & $\mathbf{3 3}$ & $\mathbf{3 7}$ & $\mathbf{3 9}$ & $\mathbf{3 8}$ & $\mathbf{3 7}$ \\
\hline Hard coal & 48 & 45 & 46 & 45 & 44 \\
\hline Lignite & 36 & 38 & 38 & 39 & 38 \\
\hline Crude oil & 14 & 15 & 14 & 15 & 16 \\
\hline Coke & 2 & 2 & 2 & 2 & 2 \\
\hline Metallic & $\mathbf{5}$ & $\mathbf{5}$ & $\mathbf{6}$ & $\mathbf{6}$ & $\mathbf{6}$ \\
\hline Iron ores and concentrates & 41 & 42 & 43 & 43 & 42 \\
\hline Crude steel & 36 & 34 & 33 & 33 & 33 \\
\hline Pig iron & 17 & 16 & 17 & 18 & 18 \\
\hline Copper concentrates & 2 & 2 & 2 & 2 & 2 \\
\hline
\end{tabular}

1 For the group of mineral raw materials the percentage refers to the total volume of consumption; for a particular mineral the percentage refers to the consumption volume of a group. 
Table 2. cont.

Tabela 2. cd.

\begin{tabular}{|c|c|c|c|c|c|}
\hline $\begin{array}{c}\text { Group of mineral raw materials/ } \\
\text { a mineral raw material }\end{array}$ & 2011 & 2012 & 2013 & 2014 & 2015 \\
\hline Zinc concentrates & 1 & 1 & 1 & 1 & 1 \\
\hline Refined copper & 1 & 1 & 1 & 1 & 1 \\
\hline Aluminium metal & 1 & 1 & 1 & 1 & 1 \\
\hline Others & 5 & 7 & 8 & 17 & 17 \\
\hline Ceramic & 17 & 18 & 17 & 18 & 18 \\
\hline Limestone & 45 & 47 & 46 & 45 & 45 \\
\hline Cement & 22 & 20 & 20 & 21 & 20 \\
\hline Cement clinker & 15 & 14 & 14 & 15 & 14 \\
\hline Gypsum and anhydrite & 4 & 5 & 5 & 5 & 5 \\
\hline Chalk & 4 & 4 & 4 & 4 & 4 \\
\hline Dolomite, raw & 2 & 2 & 3 & 3 & 4 \\
\hline Glass sand & 2 & 2 & 3 & 3 & 3 \\
\hline Lime & 2 & 2 & 2 & 2 & 2 \\
\hline Others & 3 & 3 & 4 & 4 & 4 \\
\hline Chemical & 4 & 4 & 5 & 4 & 5 \\
\hline Nitrogen-based fertilizers & 22 & 24 & 24 & 26 & 28 \\
\hline Salt & 24 & 20 & 23 & 20 & 18 \\
\hline Nitric acid & 12 & 13 & 12 & 13 & 13 \\
\hline Ammonia & 12 & 13 & 12 & 11 & 11 \\
\hline Sulphuric acid & 10 & 9 & 8 & 8 & 9 \\
\hline Calcined soda & 4 & 6 & 6 & 6 & 6 \\
\hline Potash & 4 & 4 & 4 & 5 & 5 \\
\hline Caustic soda & 4 & 4 & 5 & 4 & 5 \\
\hline Elemental sulphur & 3 & 3 & 2 & 2 & 3 \\
\hline Others & 4 & 4 & 4 & 4 & 4 \\
\hline Construction & 41 & 35 & 33 & 33 & 34 \\
\hline Natural aggregates - sand and gravel & 52 & 53 & 55 & 53 & 54 \\
\hline Natural aggregates - crushed & 44 & 42 & 41 & 42 & 41 \\
\hline Construction and road stones & 4 & 4 & 3 & 4 & 4 \\
\hline Asphalts & 1 & 1 & 1 & 1 & 1 \\
\hline Others & 1 & 1 & 1 & 1 & 1 \\
\hline Total volume (million tons) & 526 & 459 & 439 & 439 & 448 \\
\hline
\end{tabular}

Source: (GUS, own calculations). 
in the quantitative structure of the consumption, is dominated by raw materials for the production of steel and by crude steel that in common contributed $92-94 \% / y$ to the total consumption of metals, whereas demand for refined copper and aluminum has oscillated around $1 \% / y$ each.

The total estimated consumption of analyzed mineral raw materials decreased from almost 530 million tons in 2011 to $440 \mathrm{Mt}$ in 2013-2014, whereas last year it improved somewhat to $450 \mathrm{Mt} / \mathrm{y}$ (Table 2). Its fluctuations were influenced mostly by variation in demand for fuels (reduction by 5\% in 2011-2015), metals (systematic growth by $16 \%$ ), as well as construction ones (the reduction by ca. $30 \%$ in comparison with 2011).

\section{Trade in mineral raw materials in Poland}

The demand for certain mineral raw materials, due to the deficiency of deposits of sufficient quality in Poland, cannot be fully satisfied from domestic sources. As a result, almost $60 \%$ of over than 100 mineral commodities consumed in Poland have come exclusively from abroad (Table 3, Bilans gospodarki... 2015). This indicates how thoroughly the domestic economy is dependent on imported minerals, which is confirmed by the balances of the raw materials turnover in groups in 2011-2015 (Fig. 3). Among them most concerned are fuels (imports comprise $82-85 \%$ of their supply), metallic ones (45-56\%) and others (38-45\%), while the domestic demand for ceramic, construction and chemical raw materials has been met from indigenous reserves to a very wide extent (Table 3).

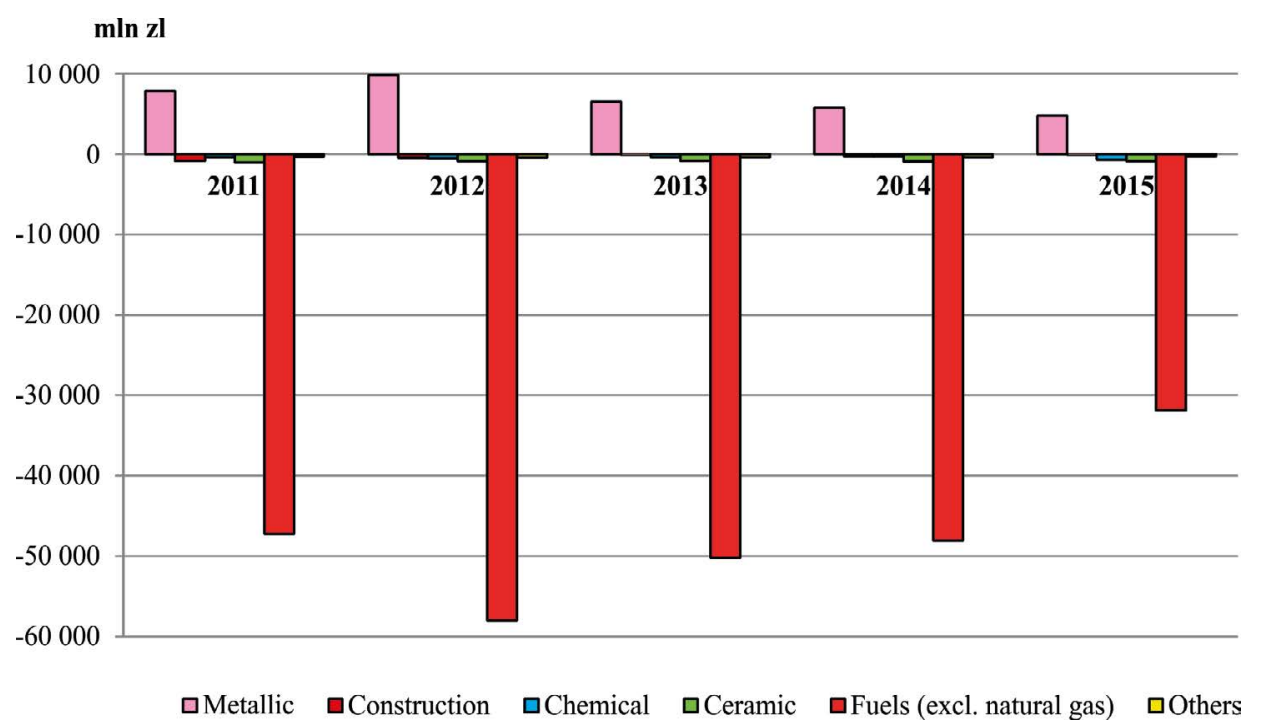

Fig. 3. Trade balances of groups of mineral raw materials in Poland, 2011-2015 (GUS, own calculations)

Rys. 3. Saldo obrotów grupami surowców mineralnych w Polsce w latach 2011-2015 (GUS, obliczenia własne) 
Table 3. The share of imports in meeting the domestic demand for mineral commodities by groups, 2011-2015 (\%)

Tabela 3. Udział importu w pokryciu krajowego zapotrzebowania na surowce mineralne w grupach w okresie 2011-2015 (\%)

\begin{tabular}{|c|c|c|c|c|c|}
\hline $\begin{array}{l}\text { Group of mineral raw materials/ } \\
\text { a mineral raw material }\end{array}$ & 2011 & 2012 & 2013 & 2014 & 2015 \\
\hline Fuels & 82 & 85 & 85 & 84 & 83 \\
\hline Crude oil & 98 & 98 & 100 & 98 & 95 \\
\hline Natural gas & 73 & 76 & 77 & 78 & 80 \\
\hline Coke & 5 & 6 & 6 & 7 & 3 \\
\hline Metallic & 55 & 56 & 55 & 45 & 45 \\
\hline Aluminium metal & 100 & 100 & 100 & 100 & 100 \\
\hline Antimony, powder, oxide etc. & 100 & 100 & 100 & 100 & 100 \\
\hline Antimony, oxide etc. & 100 & 100 & 100 & 100 & 100 \\
\hline Arsenic metal & 100 & 100 & 100 & 100 & 100 \\
\hline Arsenic trioxide & 100 & 100 & 100 & 100 & 100 \\
\hline Bismuth & 100 & 100 & 100 & 100 & 100 \\
\hline Boron metal & 100 & 100 & 100 & 100 & 100 \\
\hline Chromium metal & 100 & 100 & 100 & 100 & 100 \\
\hline Chromites & 100 & 100 & 100 & 100 & 100 \\
\hline Gallium & 100 & 100 & 100 & 100 & 100 \\
\hline Germanium commodities & 100 & 100 & 100 & 100 & 100 \\
\hline Germanium, oxides & 100 & 100 & 100 & 100 & 100 \\
\hline Indium & 100 & 100 & 100 & 100 & 100 \\
\hline Cobalt metal & 100 & 100 & 100 & 100 & 100 \\
\hline Magnesium & 100 & 100 & 100 & 100 & 100 \\
\hline Manganese metal & 100 & 100 & 100 & 100 & 100 \\
\hline Molybdenum metal & 100 & 100 & 100 & 100 & 100 \\
\hline Molybdenum ores and concentrates & 100 & 100 & 100 & 100 & 100 \\
\hline Molybdenum oxide & 100 & 100 & 100 & 100 & 100 \\
\hline Nickel metal & 100 & 100 & 100 & 100 & 100 \\
\hline Rare earth elements, yttrium and scandium & 100 & 100 & 100 & 100 & 100 \\
\hline Mercury & 100 & 100 & 100 & 100 & 100 \\
\hline Tantalum & 100 & 100 & 100 & 100 & 100 \\
\hline Tellurium & 100 & 100 & 100 & 100 & 100 \\
\hline
\end{tabular}


14

Table 3. cont.

Tabela 3. cd.

\begin{tabular}{|c|c|c|c|c|c|}
\hline $\begin{array}{l}\text { Group of mineral raw materials/ } \\
\text { a mineral raw material }\end{array}$ & 2011 & 2012 & 2013 & 2014 & 2015 \\
\hline Titanium ores and concentrates & 100 & 100 & 100 & 100 & 100 \\
\hline Calcium & 100 & 100 & 100 & 100 & 100 \\
\hline Tungsten, metal and powder & 100 & 100 & 100 & 100 & 100 \\
\hline Ferroalloys & 100 & 100 & 100 & 100 & 100 \\
\hline Zinc metal * & 52 & 62 & 74 & 100 & 98 \\
\hline Iron ores and concentrates & 60 & 63 & 62 & 61 & 60 \\
\hline Zinc concentrates & 39 & 60 & 52 & 48 & 48 \\
\hline Refined lead & 21 & 21 & 21 & 32 & 37 \\
\hline Copper ores and concentrates & 10 & 9 & 21 & 29 & 32 \\
\hline Selenium & 30 & 29 & 69 & 13 & 19 \\
\hline Refined copper & 5 & 8 & 6 & 3 & 2 \\
\hline Silver & 0 & 0 & 0 & 0 & 0 \\
\hline Rhenium & 0 & 0 & 0 & 0 & 0 \\
\hline Gold & 0 & 0 & 0 & 0 & 0 \\
\hline Ceramic & 3 & 3 & 3 & 3 & 3 \\
\hline Diatomite & 100 & 100 & 100 & 100 & 100 \\
\hline Corundum and emery & 100 & 100 & 100 & 100 & 100 \\
\hline Graphite natural & 100 & 100 & 100 & 100 & 100 \\
\hline Zircon & 100 & 100 & 100 & 100 & 100 \\
\hline Synthetic corundum & 98 & 100 & 97 & 100 & 100 \\
\hline Pumice & 100 & 100 & 100 & 100 & 100 \\
\hline Magnesite: calcined, dead-burned, fused & 100 & 100 & 100 & 100 & 100 \\
\hline Talc and steatite & 100 & 100 & 100 & 100 & 100 \\
\hline $\begin{array}{l}\text { Vermiculite, perlite, and chlorite, } \\
\text { unexpanded (raw) }\end{array}$ & 100 & 100 & 100 & 100 & 100 \\
\hline Mica & 100 & 100 & 100 & 100 & 100 \\
\hline Alumina & 100 & 100 & 100 & 100 & 100 \\
\hline Bauxite & 100 & 100 & 100 & 100 & 100 \\
\hline Andalusite - kyanite - sillimanite & 100 & 100 & 100 & 100 & 100 \\
\hline Bentonite & 70 & 74 & 76 & 87 & 86 \\
\hline Refractory clays (raw) & 72 & 70 & 71 & 74 & 76 \\
\hline
\end{tabular}


Table 3. cont.

Tabela 3. cd.

\begin{tabular}{|c|c|c|c|c|c|}
\hline $\begin{array}{c}\text { Group of mineral raw materials/ } \\
\text { a mineral raw material }\end{array}$ & 2011 & 2012 & 2013 & 2014 & 2015 \\
\hline Quartzite & 97 & 89 & 61 & 47 & 64 \\
\hline Kaolin & 44 & 49 & 46 & 43 & 43 \\
\hline Feldspar & 44 & 43 & 43 & 42 & 43 \\
\hline Quartz & 39 & 37 & 0 & 0 & 40 \\
\hline Stoneware clays & 38 & 45 & 42 & 30 & 29 \\
\hline White-firing clays & 16 & 31 & 21 & 22 & 26 \\
\hline Burnt refractory clays & 15 & 22 & 14 & 24 & 21 \\
\hline Chalk & 3 & 5 & 6 & 6 & 6 \\
\hline Dolomite calcined and dead-burned & 5 & 10 & 9 & 6 & 5 \\
\hline Lime & 5 & 3 & 4 & 5 & 5 \\
\hline Dolomite crude & 5 & 7 & 6 & 7 & 4 \\
\hline Cement & 3 & 2 & 2 & 2 & 2 \\
\hline Gypsum and anhydrite & 3 & 3 & 1 & 1 & 1 \\
\hline Cement clinker & 0 & 0 & 0 & 0 & 0 \\
\hline Limestone & 0 & 0 & 0 & 0 & 0 \\
\hline Chemical minerals & 24 & 20 & 21 & 22 & 22 \\
\hline Boron commodities & 100 & 100 & 100 & 100 & 100 \\
\hline Bromine, fluorine & 100 & 100 & 100 & 100 & 100 \\
\hline Fluorite & 100 & 100 & 100 & 100 & 100 \\
\hline Phosphorus & 100 & 100 & 100 & 100 & 100 \\
\hline Calcium phosphates & 100 & 100 & 100 & 100 & 100 \\
\hline Iodine & 100 & 100 & 100 & 100 & 100 \\
\hline Cobalt oxide and hydroxide & 100 & 100 & 100 & 100 & 100 \\
\hline Lithium oxide and hydroxide & 100 & 100 & 100 & 100 & 100 \\
\hline Lithium carbonate & 100 & 100 & 100 & 100 & 100 \\
\hline Strontium carbonate & 100 & 100 & 100 & 100 & 100 \\
\hline Potash & 100 & 100 & 100 & 100 & 92 \\
\hline Nitrogen fertilizers & 18 & 18 & 17 & 19 & 23 \\
\hline Phosphoric acid & 8 & 11 & 8 & 15 & 15 \\
\hline Salt & 24 & 13 & 21 & 13 & 13 \\
\hline
\end{tabular}


Table 3. cont

Tabela 3. cd.

\begin{tabular}{|l|r|r|r|r|r|}
\hline \multicolumn{1}{|c|}{$\begin{array}{c}\text { Group of mineral raw materials/ } \\
\text { a mineral raw material }\end{array}$} & 2011 & 2012 & 2013 & 2014 & 2015 \\
\hline Peat & 22 & 20 & 16 & 17 & 15 \\
\hline Magnesite raw & 2 & 2 & 1 & 1 & 4 \\
\hline Calcined soda & 2 & 1 & 2 & 4 & 4 \\
\hline Nitric acid & 1 & 1 & 1 & 2 & 2 \\
\hline Chlorine & 6 & 5 & 3 & 6 & 2 \\
\hline Sulphur elemental & 9 & 6 & 2 & 1 & 1 \\
\hline Sulphuric acid & 0 & 0 & 0 & 1 & 1 \\
\hline Caustic soda & 1 & 1 & 1 & 1 & 1 \\
\hline Construction minerals & $\mathbf{8}$ & $\mathbf{7}$ & $\mathbf{4}$ & $\mathbf{4}$ & $\mathbf{5}$ \\
\hline Asphalts & 18 & 27 & 9 & 9 & 11 \\
\hline Construction and road stones & 6 & 5 & 3 & 3 & 4 \\
\hline Natural aggregates - crushed & 2 & 1 & 1 & 1 & 0 \\
\hline Natural aggregates - sand and gravel & 100 & 100 & 100 & 100 & 100 \\
\hline Others & $\mathbf{4 5}$ & $\mathbf{4 5}$ & $\mathbf{4 4}$ & $\mathbf{4 1}$ & $\mathbf{3 8}$ \\
\hline Barite & 100 & 100 & 100 & 100 \\
\hline Diamonds & 100 & 100 & 100 & 100 \\
\hline Carbon black & & & & 34 & 25 \\
\hline
\end{tabular}

* High value of the ratio (share of importation in the consumption) results from the calculation of the apparent consumption (production + imports-exports); for minerals that are exported in large quantities the resulting apparent consumption can be very low and therefore the indicator measuring the share of imports is $100 \%$.

Source: (GUS, own calculations).

The most important mineral raw materials, the supply of which is heavily import-dependent, are as follows (Table 3):

- fuels: crude oil and natural gas;

- among metallic raw materials the majority of metals and/or their ores and concentrates, with the exception of: copper (although the imports of copper concentrates has been steadily increasing, supplementing domestic supplies in order to utilize the capacity of copper metallurgy), zinc (high imports of zinc concentrates result from depletion of domestic reserves of $\mathrm{Zn}-\mathrm{Pb}$ ores), as well as refined lead, selenium, refined silver, gold, and rhenium (since 2012, i.e. commencement of its production by KGHM Polska Miedź); 
- in the group of ceramic raw materials: alumina, andalusite commodities, bauxite, zircon, diatomite, graphite, corundum and emery as well as synthetic corundum, magnesites, mica, pumice, talc and steatite, wermiculite and perlite, bentonites, quartzite, as well as ceramic and refractory clays;

- chemical raw materials: boron commodities, bromine, fluorine, fluorite, phosphorus and calcium phosphates, iodine, cobalt and lithium compounds, strontium carbonate and potash;

- others: barite, diamonds, and chalk.

Examining the statistics of the production and trade of mineral raw materials in Poland it should be noted that the whole or a substantial part of demand can be met from domestic sources only for less that 30 of them. This results mainly from the sufficiently large reserve base, and sometimes also from the nature of use (raw materials of local or regional significance, not traded on a large scale). This refers to the following mineral raw materials (Table 3):

- fuels: coke and hard coal;

- metallic: refined copper and copper concentrates (imported in increasing quantities to meet the demand of copper smelters), tin metal (manufactured from secondary sources and wastes), silver, gold, refined lead;

- ceramic raw materials: chalk, dolomites (raw, calcined and dead-burned), lime, cement and cement clinker, gypsum and anhydrite, lime;

- chemical raw materials: salt, raw magnesite, calcined soda, nitric acid, chlorine, elemental sulphur, sulphuric acid, caustic soda;

- construction raw materials: building and road stones (clear decrease of the share of imports in the total supply in the last three years), natural aggregates: crushed as well as sand and gravel.

In the case of clays (stoneware, white-firing and refractory), kaolin and feldspars, the necessity of completing the national supply with the importing is linked to the shortage of minerals of appropriate quality on the domestic market as well as the high demand of the ceramic industry far exceeding supplies, despite the occurrence of deposits of these minerals in Poland (Szamałek 2011). For a relatively small number of mineral raw materials the scale of the production allow for their foreign sale. However, their list is definitely shorter than the register of minerals imported to Poland (Table 4).

In the years 2011-2015 the largest percentage of the marketed production was shown by the group of metallic raw materials (64-85\%), including: lead concentrates, ferroalloys, cadmium, silver, zinc metal, lead metal, refined copper and rhenium (Table 4). It is noticeable that the share of foreign sales in the domestic production of metallic raw materials has clearly increased throughout the analyzed period despite the fact that their positive balance of trade decreased more than half (Fig. 3, Table 5). That was a result of low prices of the majority of metals, especially copper and silver, on international markets. It should be underlined, however, that metallic raw materials is the only group systematically generating revenue in the domestic trade balance. A relatively important role has been also played by the chemical raw 
Table 4. The percentage of the domestic production sold abroad (\%)

Tabela 4. Odsetek krajowej produkcji surowców mineralnych przeznaczanej na eksport (\%)

\begin{tabular}{|c|c|c|c|c|c|}
\hline $\begin{array}{c}\text { Group of mineral raw materials/ } \\
\text { a mineral raw material }\end{array}$ & 2011 & 2012 & 2013 & 2014 & 2015 \\
\hline Fuels & 16 & 15 & 20 & 19 & 19 \\
\hline Coke & 69 & 72 & 71 & 70 & 66 \\
\hline Hard coal & 9 & 9 & 14 & 12 & 13 \\
\hline Metallic & 64 & 69 & 78 & 85 & 79 \\
\hline Lead, ores and concentrates & 100 & 100 & 100 & 100 & 100 \\
\hline Ferroalloys & 100 & 100 & 100 & 100 & 100 \\
\hline Cadmium & 100 & 100 & 100 & 100 & 100 \\
\hline Silver & 100 & 100 & 100 & 100 & 100 \\
\hline Zinc metal & 78 & 82 & 94 & 100 & 100 \\
\hline Rhenium & 0 & 100 & 100 & 100 & 100 \\
\hline Lead metal & 43 & 44 & 43 & 59 & 58 \\
\hline Refined copper & 57 & 59 & 61 & 54 & 52 \\
\hline Ceramic & 3 & 3 & 4 & 4 & 4 \\
\hline Refractory clays (raw) & 10 & 8 & 10 & 10 & 11 \\
\hline Lime & 5 & 5 & 5 & 7 & 9 \\
\hline Kaolin & 8 & 8 & 6 & 6 & 8 \\
\hline Glass sand & 10 & 9 & 7 & 9 & 6 \\
\hline Lime & 1 & 1 & 1 & 1 & 3 \\
\hline Cement & 2 & 2 & 3 & 3 & 3 \\
\hline Feldspar & 2 & 2 & 2 & 2 & 1 \\
\hline Dolomite crude & 2 & 2 & 2 & 2 & 1 \\
\hline Burnt refractory clays & 1 & 2 & 1 & 1 & 0 \\
\hline Chemical & 24 & 22 & 20 & 23 & 22 \\
\hline Sulphur, elemental & 43 & 53 & 49 & 56 & 49 \\
\hline Nitrogen fertilizers & 34 & 34 & 32 & 33 & 31 \\
\hline Phosphate fertilizers & 12 & 9 & 6 & 7 & 24 \\
\hline Sulphuric acid & 19 & 20 & 14 & 17 & 19 \\
\hline Ammonia & 5 & 6 & 6 & 9 & 11 \\
\hline Phosphoric acid & 11 & 10 & 20 & 16 & 8 \\
\hline
\end{tabular}


Table 4. cont.

Tabela 4. cd.

\begin{tabular}{|l|r|r|r|r|r|}
\hline $\begin{array}{c}\text { Group of mineral raw materials/ } \\
\text { a mineral raw material }\end{array}$ & 2011 & 2012 & 2013 & 2014 & 2015 \\
\hline Caustic soda & 6 & 7 & 7 & 8 & 5 \\
\hline Chlorine & 5 & 4 & 6 & 6 & 3 \\
\hline Calcined soda & 36 & 0 & 0 & 0 & 0 \\
\hline Construction & 1 & 1 & 2 & 2 & 2 \\
\hline Asphalts & 26 & 32 & 35 & 38 & 42 \\
\hline Construction and road stones & 3 & 4 & 5 & 4 & 4 \\
\hline Natural aggregates - crushed & 1 & 1 & 2 & 2 & 2 \\
\hline Others & 5 & 5 & 5 & 4 & 4 \\
\hline Peat & 5 & 5 & 5 & 4 & 4 \\
\hline
\end{tabular}

Source: (GUS, own calculations).

materials, including: elemental sulphur, nitrogen and phosphate fertilizers, sulphuric acid, ammonia and phosphoric acid. The slight increase of the export-share indicator has been observed in the last few years for fuels, in which the most export-oriented raw material is coke. This, coupled with reduction in hard coal importation, resulted in the relaxation of the deep trade deficit of this group. Simultaneous improvement in foreign sales of hard coal led to a positive value of the trade balance of this commodity. The share of exports in the total production of chemical raw materials remained at $20-24 \% / y$ and its fluctuations were the result of variable sales of elemental sulphur, sulphuric acid and phosphoric acid, while the exports of calcined soda completely disappeared (Table 5). Consequently, the trade balance of this group has been slightly negative. The foreign trade of construction raw materials has been carried out on a much smaller scale, limited to border areas by the geographic proximity of the manufacturers. Following the reduced purchase of crushed aggregates as well as construction and road stones, accompanied by increased exporting of some commodities (e.g. asphalts, natural aggregates - sand and gravel), the deficit in foreign trade of construction raw materials clearly decreased, especially in 2013 and 2015 (Table 5). In the case of ceramic raw materials, both indices, i.e. the share of imports in the consumption and the percentage of the production sold abroad, have been low, whereas their trade balances have been always negative, despite a recent improvement of financial results of the sale of lime, limestone, cement clinker and cement. This can be explained by the fact that many of these commodities are scarce in Poland (e.g. alumina, corundum, talc, bauxite, natural graphite, andalusite raw materials, bentonites, diatomite, vermiculite etc.), or the raw materials imported are highly processed and of a better quality than those available on the domestic market. 
20

Lewicka and Burkowicz 2017 / Gospodarka Surowcami Mineralnymi - Mineral Resources Management 33(4), 5-28

Table 5. Trade balances of selected mineral commodities in Poland, by groups (million PLN)

Tabela 5. Salda obrotów handlowych wybranymi surowcami mineralnymi w Polsce według grup (mln zł)

\begin{tabular}{|c|c|c|c|c|c|}
\hline Group of mineral raw materials/ a mineral raw material & 2011 & 2012 & 2013 & 2014 & 2015 \\
\hline Fuels excl. natural gas & -47238 & -57977 & -50215 & -48066 & -31871 \\
\hline Coke & 8037 & 6256 & 5344 & 4790 & 4452 \\
\hline Hard coal & -2905 & -908 & 214 & -362 & 134 \\
\hline Crude oil & -52370 & -63324 & -55774 & -52494 & -36457 \\
\hline Metallic & 7942 & 9905 & 6613 & 5809 & 4869 \\
\hline Refined copper & 8209 & 8136 & 7653 & 6526 & 6119 \\
\hline Silver & 3961 & 4234 & 2695 & 2694 & 2679 \\
\hline Zinc metal & 441 & 392 & 508 & 1018 & 877 \\
\hline Gold & 290 & 1802 & 581 & 358 & 568 \\
\hline Refined lead & 33 & 105 & 116 & 225 & 149 \\
\hline Crude steel & 71 & 63 & 71 & 67 & 49 \\
\hline Cadmium & 5 & 2 & 3 & 4 & 25 \\
\hline Selenium & 14 & 17 & 10 & 5 & 3 \\
\hline Rhenium & 0 & 58 & 34 & 4 & 2 \\
\hline Tantalum & 0 & 0 & 1 & 0 & 1 \\
\hline Arsenic (arsenic trioxide) & 0 & 0 & 0 & 0 & 0 \\
\hline Germanium & 0 & 0 & 0 & 0 & 0 \\
\hline Gallium & 0 & 0 & 0 & 0 & 0 \\
\hline Indium & 0 & 0 & 0 & -1 & 0 \\
\hline Boron metal & 0 & 0 & 0 & 0 & 0 \\
\hline Arsenic & 0 & 0 & 0 & 0 & 0 \\
\hline Tellurium & -2 & -1 & 0 & -1 & 0 \\
\hline Germanium oxides & -2 & -2 & -1 & -1 & -1 \\
\hline Calcium & -1 & 0 & 1 & 1 & -1 \\
\hline Mercury & -5 & -3 & -5 & -4 & -1 \\
\hline Antimony, powder & -1 & -1 & -2 & -1 & -1 \\
\hline Chromium metal & -2 & -1 & -2 & -2 & -2 \\
\hline Tungsten - metal and powder & -6 & -2 & 7 & 5 & -2 \\
\hline Bismuth & -2 & -2 & -2 & -2 & -2 \\
\hline Rare earth elements & 10 & -3 & -2 & -2 & -2 \\
\hline
\end{tabular}


Table 5. cont.

Tabela 5. cd.

\begin{tabular}{|c|c|c|c|c|c|}
\hline Group of mineral raw materials/ a mineral raw material & 2011 & 2012 & 2013 & 2014 & 2015 \\
\hline Cobalt metal & -4 & -4 & -4 & -5 & -3 \\
\hline Molybdenum metal & -1 & -2 & 0 & -2 & -3 \\
\hline Molybdenum ores and concentrates & -2 & 0 & -3 & -3 & -5 \\
\hline Manganese & -4 & -6 & -7 & -7 & -9 \\
\hline Molybdenum oxides & -11 & -12 & -8 & -9 & -11 \\
\hline Chromites & -26 & -26 & -26 & -17 & -18 \\
\hline Antimony, oxides & -37 & -33 & -24 & -24 & -20 \\
\hline Tin metal & -75 & -54 & -39 & -25 & -47 \\
\hline Magnesium & -55 & -48 & -76 & -77 & -71 \\
\hline Titanium ores and concentrates & -74 & -149 & -119 & -83 & -79 \\
\hline Nickel metal & -172 & -156 & -64 & 24 & -101 \\
\hline Ferroalloys & 12 & -50 & 6 & -278 & -315 \\
\hline Iron ores and concentrates & -2119 & -2030 & -2160 & -1730 & -1233 \\
\hline Copper concentrates & -357 & -329 & -800 & -1110 & -1487 \\
\hline Aluminium metal & -2149 & -1990 & -1728 & -1741 & -2172 \\
\hline Ceramic & -1031 & -874 & -815 & -889 & -866 \\
\hline Lime & 8 & 17 & 18 & 22 & 48 \\
\hline Limestone & 10 & 12 & 22 & 17 & 39 \\
\hline Cement clinker & 3 & 16 & 22 & 32 & 10 \\
\hline Cement & -92 & -9 & 8 & 9 & 10 \\
\hline Pumice & 2 & 4 & 4 & 3 & 1 \\
\hline Dolomite crude & -1 & -3 & -1 & -4 & -1 \\
\hline Quartz & -3 & -2 & -2 & -2 & -1 \\
\hline Zircon & -4 & -6 & -4 & -3 & -3 \\
\hline Gypsum and anhydrite & -9 & -9 & -1 & -1 & -3 \\
\hline Quartzite & -2 & -5 & -6 & -5 & -5 \\
\hline Mica & -6 & -6 & -6 & -6 & -6 \\
\hline Diatomite & -13 & -13 & -12 & -12 & -7 \\
\hline Burnt refractory clays & -6 & -8 & -6 & -8 & -8 \\
\hline Vermiculite, perlite and chlorite, unexpanded (raw) & -7 & -8 & -8 & -9 & -8 \\
\hline
\end{tabular}


22

Table 5. cont.

Tabela 5. cd.

\begin{tabular}{|c|c|c|c|c|c|}
\hline Group of mineral raw materials/ a mineral raw material & 2011 & 2012 & 2013 & 2014 & 2015 \\
\hline Corundum and emery & -6 & -4 & -6 & -9 & -10 \\
\hline White-firing clays & -6 & -8 & -9 & -10 & -11 \\
\hline Bentonite & -30 & -38 & -11 & -23 & -17 \\
\hline Stoneware clays & -23 & -24 & -25 & -18 & -19 \\
\hline Andalusite - kyanite - sillimanite & -20 & -25 & -27 & -31 & -22 \\
\hline Graphite natural & -35 & -20 & -24 & -27 & -23 \\
\hline Chalk & -19 & -24 & -29 & -33 & -33 \\
\hline Bauxite & -34 & -40 & -29 & -30 & -37 \\
\hline Talc and steatite & -33 & -37 & -46 & -39 & -45 \\
\hline Kaolin & -48 & -48 & -50 & -51 & -48 \\
\hline Feldspar & -95 & -84 & -89 & -90 & -92 \\
\hline Refractory clays (raw) & -76 & -75 & -75 & -86 & -97 \\
\hline Alumina & -115 & -133 & -131 & -136 & -144 \\
\hline Synthetic corundum (electro corundum) & -107 & -117 & -129 & -143 & -148 \\
\hline Magnesite: calcined, dead-burned, and fused & -264 & -177 & -165 & -195 & -186 \\
\hline Chemical & -206 & -285 & -139 & 18 & -254 \\
\hline Nitrogen fertilizers & 899 & 1024 & 842 & 889 & 591 \\
\hline Ammonia & 114 & 233 & 212 & 282 & 330 \\
\hline Elemental sulphur & 115 & 239 & 147 & 193 & 221 \\
\hline Phosphate fertilizers & 54 & 33 & 13 & 18 & 103 \\
\hline Caustic soda & 57 & 101 & 102 & 86 & 70 \\
\hline Sulphuric acid & 104 & 58 & 33 & 36 & 55 \\
\hline Salt & 0 & 32 & 14 & 2 & 29 \\
\hline Chlorine & -4 & -3 & 6 & 3 & 4 \\
\hline Nitric acid & 0 & 6 & 16 & 8 & 1 \\
\hline Bromine, fluorite & 0 & -1 & -1 & -1 & 0 \\
\hline Iodine & -2 & -2 & -3 & 0 & 0 \\
\hline Cobalt oxide and hydroxide & -3 & -1 & -1 & -1 & -1 \\
\hline Strontium carbonate & -2 & -2 & -2 & -2 & -2 \\
\hline Lithium oxide and hydroxide & -2 & -2 & -2 & -2 & -2 \\
\hline
\end{tabular}


Table 5. cont.

Tabela 5. cd.

\begin{tabular}{|l|r|r|r|r|r|}
\hline Group of mineral raw materials/ a mineral raw material & 2011 & 2012 & 2013 & 2014 & 2015 \\
\hline Magnesite raw & -1 & -1 & -1 & -1 & -3 \\
\hline Lithium carbonate & -3 & -3 & -3 & -3 & -4 \\
\hline Boron commodities & -2 & -4 & -4 & -6 & -9 \\
\hline Fluorite & -11 & -12 & -11 & -12 & -9 \\
\hline Phosphoric acid & 39 & 5 & 96 & 64 & -10 \\
\hline Calcined soda & 258 & -12 & -20 & -36 & -41 \\
\hline Phosphorus & -127 & -137 & -182 & -171 & -164 \\
\hline Calcium phosphates & -684 & -699 & -383 & -391 & -462 \\
\hline Potash & -1005 & -1132 & -1007 & -938 & -952 \\
\hline Construction & $-\mathbf{8 3 2}$ & $-\mathbf{4 6 0}$ & $-\mathbf{5 4}$ & $-\mathbf{2 7 8}$ & $-\mathbf{2}$ \\
\hline Asphalts & -16 & 200 & 304 & 195 & 420 \\
\hline Natural aggregates - sand and gravel & -63 & -37 & 1 & 1 & 8 \\
\hline Natural aggregates - crushed & -257 & -169 & -49 & -69 & -99 \\
\hline Construction and road stones & -495 & -454 & -309 & -405 & -331 \\
\hline Others & $-\mathbf{3 1 9}$ & $-\mathbf{3 9 5}$ & $-\mathbf{3 6 6}$ & $-\mathbf{3 6 3}$ & $\mathbf{- 2 6 6}$ \\
\hline Barite & -12 & -16 & -11 & -18 & -16 \\
\hline Diamonds & -22 & -16 & -17 & -21 & -24 \\
\hline Peat & -45 & -41 & -41 & -45 & -39 \\
\hline Carbon black & $-\mathbf{5 0} \mathbf{0 8 5}$ & $\mathbf{- 4 4} \mathbf{9 7 7}$ & $\mathbf{- 4 3} \mathbf{7 6 9}$ & $-\mathbf{2 8 ~ 3 9 0}$ \\
\hline Total balance & -322 & -296 & -280 & -187 \\
\hline
\end{tabular}

Source: (GUS, own calculations).

The presented trade statistics of mineral raw materials in Poland clearly show that deep deficit in turnover is a consequence of the imports of crude oil. Certainly, if the value of importing of natural gas was also taken into account (the supply of which has come basically from abroad, recently in $80 \%$, Table 3 ), the total financial results of the trade would be much worse. Unfortunately, no information on the costs of gas importation is available. In light of the EU directives limiting the utilization of hard coal and lignite it can be assumed that Poland's dependence on foreign deliveries of crude oil and natural gas will be continued, and thus the negative balance of the trade of mineral raw materials is expected to be widened. 
The deficit in the trade of mineral raw materials in Poland has alleviated in recent years, improving from over -50 million zlotys in 2012 to -28 million zlotys in 2015 , basically due to costs reduction of fuels imports being the aftermath of low prices of crude oil and natural gas on the international markets, especially in the last two years (Table 5, Fig. 3). Therefore, the simultaneous reduction of revenues from the foreign sales of metallic raw materials (due to deterioration of the exchange metal quotations, especially copper and silver) has been felt less severely (Bachowski and Kudełko 2015).

\section{Summary}

An assessment of current demand for mineral raw materials in the domestic economy has been performed on the basis of values and volumes of their consumption, trade balances, as well as indices of the share of imports in the consumption and percentage of production sold abroad, in the years 2011-2015.

The total estimated volume of consumption of the analyzed raw materials in Poland decreased from around 530 million tons in 2011 to $440-450 \mathrm{Mt} / \mathrm{y}$. This was mostly influenced by fluctuations of demand for fuels (basically coal) and aggregates. Simultaneously, the total value of the mineral commodities was reduced from 124-126 to only 92 billion zlotys, i.e. by around $27 \%$, basically owing to $35 \%$ decline of fuels demand value (resulting from low fuels prices).

In the case of numerous mineral raw materials, due to the lack or deficiency of their deposits in Poland, the demand cannot be fully satisfied from domestic sources (Szamałek 2011; Nieć et al. 2014). As a consequence, around $60 \%$ of over 100 mineral commodities have to be imported. This shows how thoroughly Poland is dependent on foreign deliveries. This was confirmed by the deep trade deficit in 2011-2015. Major contributors to the negative turnover result are: fuels (imports stands for $82-85 \%$ of their domestic supplies), metallic raw materials (45-56\%) and others (38-45\%), while the demand for ceramic, construction, and chemical raw materials to a large extent is met from indigenous sources.

There are fewer than 30 mineral commodities, the supplies of which have come entirely or mostly from domestic sources, which is related to sufficiently large reserve base or local scale of the use. This refers to: refined copper, silver, gold, refined lead, rhenium, selenium, coke, hard coal, salt, elemental sulphur, limestone, glass sand, cement clinker and cement, construction and road stone, natural aggregates (crushed, sand and gravel), chalk, dolomites (raw, calcined, dead burned), gypsum and anhydrite. In the case of ceramic and refractory clays, kaolin, and feldspar, the necessity of supplementing their domestic supplies by imports has resulted from shortages of good quality raw materials on the market, despite the occurrence of their deposits in Poland.

The statistics discussed in the article have indicated that future demand for many of analyzed mineral raw materials to an increasing extent will be satisfied by imports. This will 
concern both minerals brought to Poland owing to the deficiency of own sources, such as: iron ores and concentrates, aluminum, ferroalloys, phosphates, and potash, as well as e.g. raw materials for the production of refined copper (copper concentrates, anode copper) and metallic zinc (zinc concentrates), the domestic supply of which looks to be insufficient with regard to the smelters capacities. Another reason for Poland's growing import dependency on the foreign deliveries of mineral raw materials is the lack of the possibility for the production of commodities of the highest quality from deposits occurring in the country. In various extents this refers to e.g.: ceramic clays (white-firing, stoneware and refractory), kaolin, magnesite (calcined, dead-burned and fused), chalk, and feldspar. The only exceptions are construction raw materials and some ceramic ones, for which the demand can be entirely or mostly satisfied from domestic sources. The scale of the consumption of such fuels as hard coal and lignite, the reserves of which seem to be sufficient to meet the domestic consumers' needs, may be greatly reduced in light of EU directives and planned restrictions relating to the use of these fossil fuels. The possible alternative is increasing utilization of renewable energy sources, while in the case of metals - improved recycling of scrap and metal-bearing wastes.

The work was carried out as part of the statutory activity of the Mineral and Energy Economy Research Institute Polish Academy of Sciences.

\section{REFERENCES}

Bachowski, C. and Kudełko, J. 2015. Jak długo trwać będzie bessa na rynku metali nieżelaznych. Zeszyty Naukowe Instytutu Gospodarki Surowcami Mineralnymi i Energia PAN nr 91, pp. 5-21 (in Polish).

Bilans gospodarki surowcami mineralnymi Polski i świata 2013. 2015. Eds. T. Smakowski, K. Galos and E. Lewicka. Warszawa: Wyd. PIG-PIB.

Galos et al. 2010 - Galos, K., Lewicka, E. and Smakowski, T. 2010. Podstawowe trendy zmian w gospodarowaniu surowcami mineralnymi w Polsce na przestrzeni ostatnich dwudziestu lat. Zeszyty Naukowe Instytutu Gospodarki Surowcami Mineralnymi i Energia PAN nr 79, pp. 7-30 (in Polish).

Galos, K. and Lewicka, E. 2016. Ocena znaczenia surowców mineralnych nieenergetycznych dla gospodarki krajowej. Zeszyty Naukowe Instytutu Gospodarki Surowcami Mineralnymi i Energia PAN nr 92, pp. 7-36 (in Polish).

Galos, K. and Szamałek, K. 2011 Ocena bezpieczeństwa surowcowego Polski w zakresie surowców nieenergetycznych. Zeszyty Naukowe Instytutu Gospodarki Surowcami Mineralnymi i Energia PAN nr 81, pp. 37-58 (in Polish).

GUS - niepublikowane dane statystyczne produkcji i obrotów handlu zagranicznego za lata 2011-2015 (unpublished statistics of the production and trade in 2011-2015).

Minerals Yearbook of Poland 2013. 2014. Eds. T. Smakowski, K. Galos and E. Lewicka. Warszawa: Wyd. PIG-PIB (in English).

Nieć et al. 2014 - Nieć, M., Galos, K. and Szamałek, K. 2014. Main challenges of minerals resources policy of Poland. Resources Policy 42, pp. 93-103.

Szamałek, K. 2011. Ocena wystarczalności krajowych złóż udokumentowanych [In:] Bilans perspektywicznych zasobów kopalin Polski wedtug stanu na 31.XII.2009 r. Eds. S. Wołowicz, T. Smakowski T. and S. Speczik (in Polish). 


\section{ZMIANY STRUKTURY ZAPOTRZEBOWANIA NA SUROWCE MINERALNE W POLSCE \\ W LATACH 2011-2015}

Słowa kluczowe

surowce mineralne, produkcja, zapotrzebowanie, handel zagraniczny, saldo obrotów

\section{Streszczenie}

Ocenę obecnych potrzeb surowcowych gospodarki krajowej oraz możliwości ich zaspokojenia przeprowadzono dla okresu 2011-2015 na podstawie analizy wielkości i wartości zużycia, a także wskaźnika udziału importu w zapotrzebowaniu oraz odsetka produkcji przeznaczanej na eksport. Poszczególne surowce mineralne będące przedmiotem krajowej konsumpcji przyporządkowano do grup odpowiadających ich głównemu kierunkowi użytkowania, wyróżniając surowce: energetyczne, metaliczne, ceramiczne, chemiczne, budowlane oraz inne. Uzupełnienie przedstawionych relacji popytowo-podażowych stanowią salda obrotów wybranymi surowcami mineralnymi. Analiza danych statystycznych wykazała, że zapotrzebowanie na znaczną część surowców mineralnych w Polsce jest i przypuszczalnie będzie musiało być zaspokajane importem. Powodem utrzymującego się uzależnienia od zagranicznych dostaw jest brak lub niewystarczająca baza zasobowa, a także niska jakość kopalin w złożach występujących na terenie kraju. Jedynie w przypadku większości surowców budowlanych i części ceramicznych, a także surowców stanowiących przedmiot znaczącej sprzedaży zagranicznej (np. miedź elektrolityczna, srebro, cynk, siarka, surowce ołowiu, czy selen), można stwierdzić, że ich rodzima podaż w pełni zaspokaja potrzeby krajowej gospodarki. Natomiast skala użytkowania surowców energetycznych, takich jak węgiel kamienny i brunatny, które zajmują istotną pozycję w tzw. miksie energetycznym Polski, w świetle unijnych dyrektyw zmierzających do ograniczania stosowania paliw stałych, może ulec ograniczeniu. Alternatywą jest rozwój wykorzystania odnawialnych źródeł energii, a w przypadku metali - intensyfikacja recyklingu złomów i odpadów metalonośnych.

\section{THE CHANGES IN THE STRUCTURE OF MINERAL RAW MATERIALS NEEDS IN POLAND BETWEEN 2011-2015}

$$
\text { Keywords }
$$

production, demand, mineral raw materials, foreign trade, trade balance

\section{Abstract}

An assessment of current demand for mineral raw materials in the domestic economy as well possibilities to satisfy the needs of the industry has been performed for the period 2011-2015 on the basis of estimated values and volumes of their consumption, as well as indices of the share of importation in the consumption and percentage of production sold abroad. Domestically consumed mineral raw materials have been assigned to groups corresponding to the main way of their usage, distinguishing: 
fuels, metallic, ceramic, chemical, construction, and others. Complementary to the presented demand-supply relations are trade balances of selected commodities. Analysis of available statistical data showed that the demand for substantial number of mineral raw materials in Poland has been met by imports and this probably will be continued in future. The reasons for Poland's sustained import dependency of mineral raw materials is the lack or insufficient reserve base, as well as low quality of raw materials available from deposits occurring in the country. The exceptions are construction raw materials and some ceramic ones, as well minerals exported in significant qualities (e.g.: refined copper, silver, zinc, sulphur, lead raw materials, or selenium), for which it can be stated that their domestic supplies may fully satisfy the demand of the national economy. On the other hand, the scale of utilization of such fuels as hard coal and lignite, which represent very significant item in Poland's total energy mix, may be greatly reduced in the light of EU directives aimed at restricted use of these fossil fuels. The possible alternative is development of the use of renewable energy sources, while in the case of metals - improved recycling of scrap and metal-bearing wastes. 
